For Internal Distribution Only

Accelerator Division

Alternating Gradient Synchrotron Department BROOKHAVEN NATIONAL LABORATORY

Upton, New York 11973

Accelerator Division

Technical Note

AGS/AD/Tech. Note No. 414

\title{
RADIATION PROTECTION STUDIES DURING HIGH INTENSITY RUNNING AT AGS \\ RADIATION EXPOSURE AROUND THE AGS RING AND \\ IN THE SEB EXPERIMENTAL AREAS
}

E. Lessard, K. Reece, and R. Miltenberger*

March 14, 1995

*S\&EP Div. 
Radiation Protection Studies During High Intensity Running At AGS

Radiation Exposure Around The AGS Ring And In The SEB Experimental Areas

Table Of Contents

Page

Summary

2

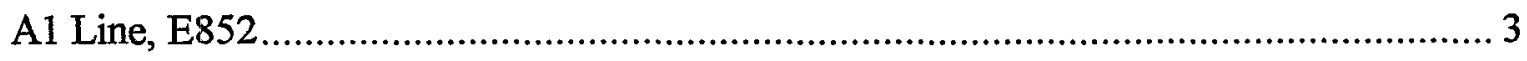

A2 Line, E865

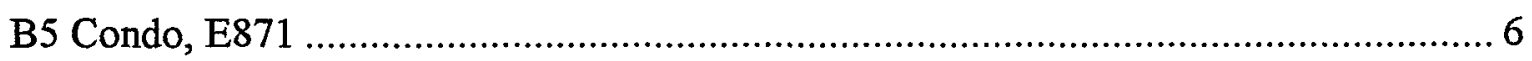

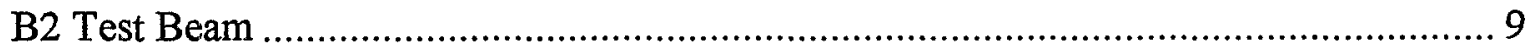

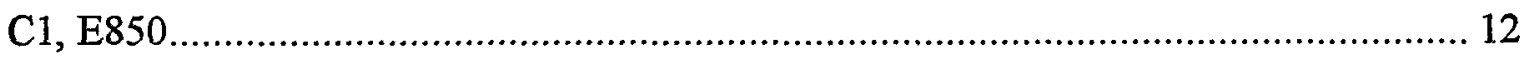

C8, E890

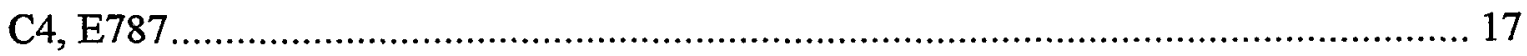

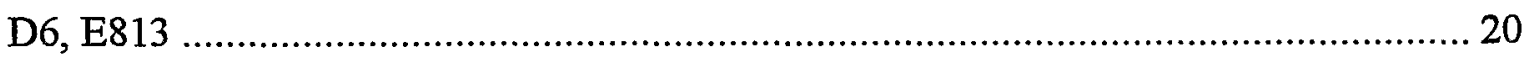

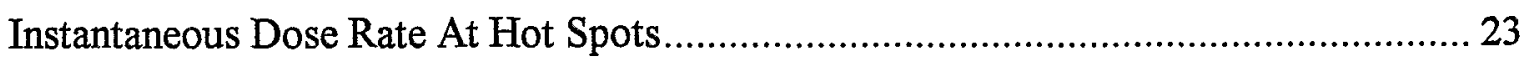

Airborne Radioactivity From Cooling Tower 2 …................................................... 27

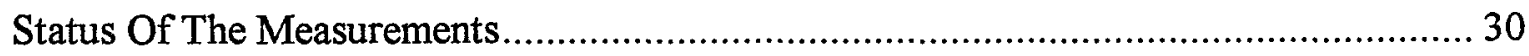

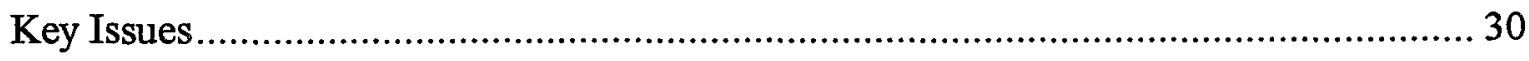

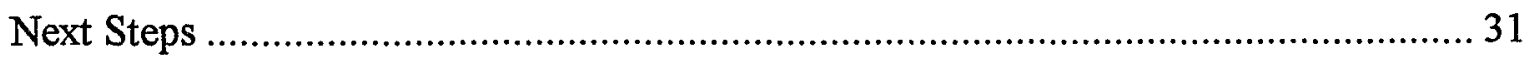




\section{Summary}

On February 9 and 10, 1995, the AGS Department and pertinent S\&EP Division staffs undertook studies of neutron and gamma dose rates in and around the AGS Complex during high-intensity proton running. The relationship of dose rate to machine intensity, and the neutron and gamma components of the radiation field were studied. The use of various radiation-weighting-factors for neutrons was reviewed. Airborne contamination at the target gates and radiation exposure from a cooling tower plume were observed and measured.

The study indicated that the AGS Department should add shielding to trenches at the EEA Ramp and the trench running through the Old D Gate Crotch. This concern was brought to the attention of the Head of the Experimental Areas Group and the Radiation Safety Committee (RSC). The shields around AGS Ring escape hatches, the South Plug Door, the North Plug Door and North Catwalk should be upgraded. This was discussed with a sub-Committee of the RSC and temporary shielding was added to the South Plug Door ramp. Final shield design shall go before the full Committee.

Reduced occupancy of certain areas such as the B5 Condo and the Target Desk was considered important in order to avoid unwarranted dose. Thus, the Target Desk occupancy has been limited and the liaison physicist for the B5 Line has been apprised of the situation at the B5 Condo.

The set point of certain alarming chipmunks needed to be changed in order to allow continuous and safe operation. The use of Chipmunks in unoccupied, secured areas that are continuously in the alarm state needs to be re-evaluated. Certain chipmunks needed to be shielded from shine from water pipes since it was interfering with their primary protection mode which is to detect beam faults. These concerns have been reviewed by the RSC and they shall follow-up.

Efforts should be undertaken by HP staff at AGS to ensure that the posted dose rate accurately reflects the total dose rate. Postings do not report the correct proportion of neutron and gamma dose particularly near water manifolds. Quality factor measurements appear sufficient for the most part; however, a few additional quality factor measurements could be performed in the A2 and C1 Lines. The Head of the S\&EP Facility Support Section (FSS) has been apprised of these concerns.

The dose to staff in Building 911 from cooling tower plumes is estimated to be less than 3 mrem per 20 week running period. However, the AGS Department needs to fully characterize the gamma shine from the cooling tower plumes. The FSS is assisting in this effort by placing environmental dosimeters in offices in Building 911 and other similar areas. The ad hoc AGS Committee for Cooling Water Shielding was apprised of these recent measurements, and has begun the process of reviewing long-term and short-term options for dose reduction. 


\section{A1 Line, E852}

\section{Radiation Weighting Factor Measurements}

Radiation weighting factors, often called quality factors or $\mathrm{Q}$, are determined from measurements normally made by HP staff at AGS with a $\mathrm{BF}_{3}$ tube and a GM tube. The $\mathrm{BF}_{3}$ tube is sensitive to neutrons, and the GM tube is predominantly sensitive photons and muons. Other studies by health physicists from the S\&EP Division employ more complex instruments and analysis. No measurements were taken during this study period at this location.

Prior measurements were made in 1993 by J. Preisig of the S\&EP Division using a Bonner-Multisphere LiI Spectrometer and a C-11 plastic scintillator. These have shown the radiation weighting factor for neutrons in this area to range up to 6.3. However, neutrons were a small fraction of the mixed radiation field at this location; that is, gamma radiation near the $\mathrm{A} 1$ Line that dominated the total dose rate.

Instantaneous Measurements

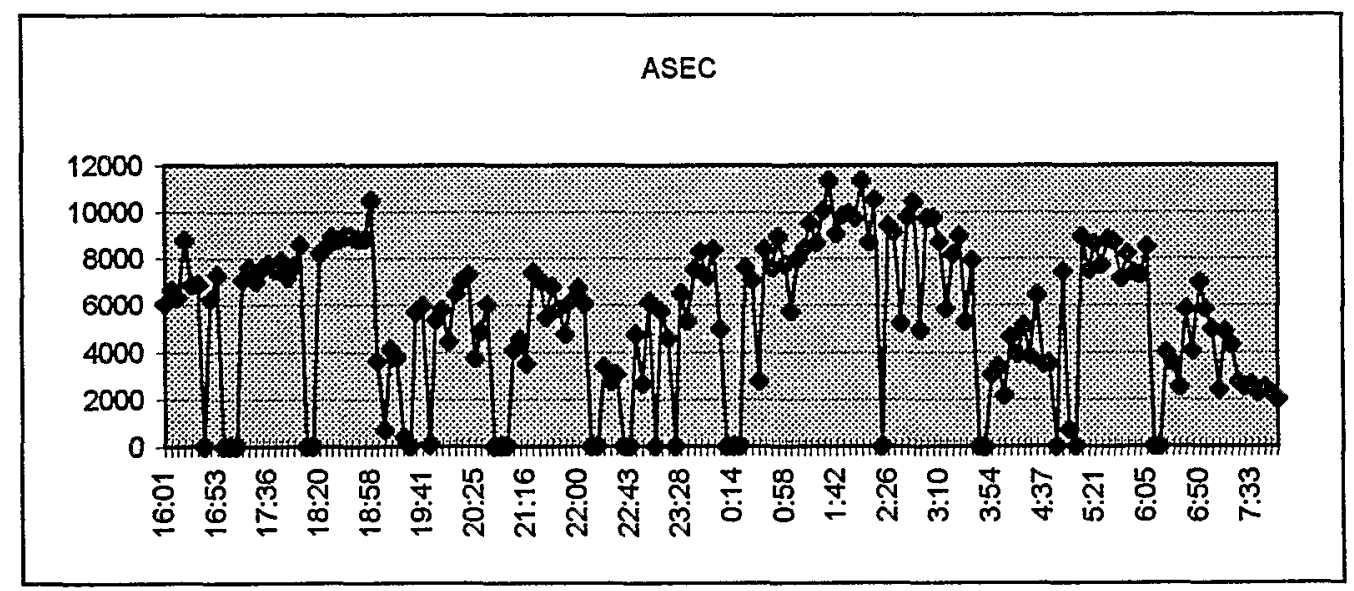

Average Area Dose Rate and Intensity

The eight-hour average was recorded by area radiation monitors. The radiation weighting factor used in these instruments is pre-set to a value of 2.5. The chipmunk sees an absorbed dose rate, in $\mathrm{mrad} / \mathrm{h}$, and we assume it is from a mixed radiation field of half gamma and half neutron. We assume $\mathrm{Q}=5$ for the neutron component and $\mathrm{Q}=1$ for the gamma component. The instrument multiplies the absorbed dose by 2.5 in order to give a response in $\mathrm{mrem} / \mathrm{h}$. The results for this area were: 


\begin{tabular}{|c|c|c|}
\hline Date/Time & $\begin{array}{l}\text { A Target Intensity, } \\
8 \text { hour average, } \\
\text { TP }\end{array}$ & $\begin{array}{l}\text { A Line Catwalk } \backslash \text { A-Target Shield Top, (44) } \\
8 \text { hour average, } \\
\text { mrem } / \mathrm{h}\end{array}$ \\
\hline Feb 9,0 to 8 & 2.8 & 4.4 \\
\hline Feb 9,8 to 4 & 2.7 & 3.3 \\
\hline Feb 9,4 to 12 & 3.4 & 5.0 \\
\hline Feb 10,0 to 8 & 3.4 & 4.9 \\
\hline Feb 10,8 to 4 & 2.3 & 3.0 \\
\hline Feb 10,4 to 12 & 1.1 & 1.2 \\
\hline
\end{tabular}

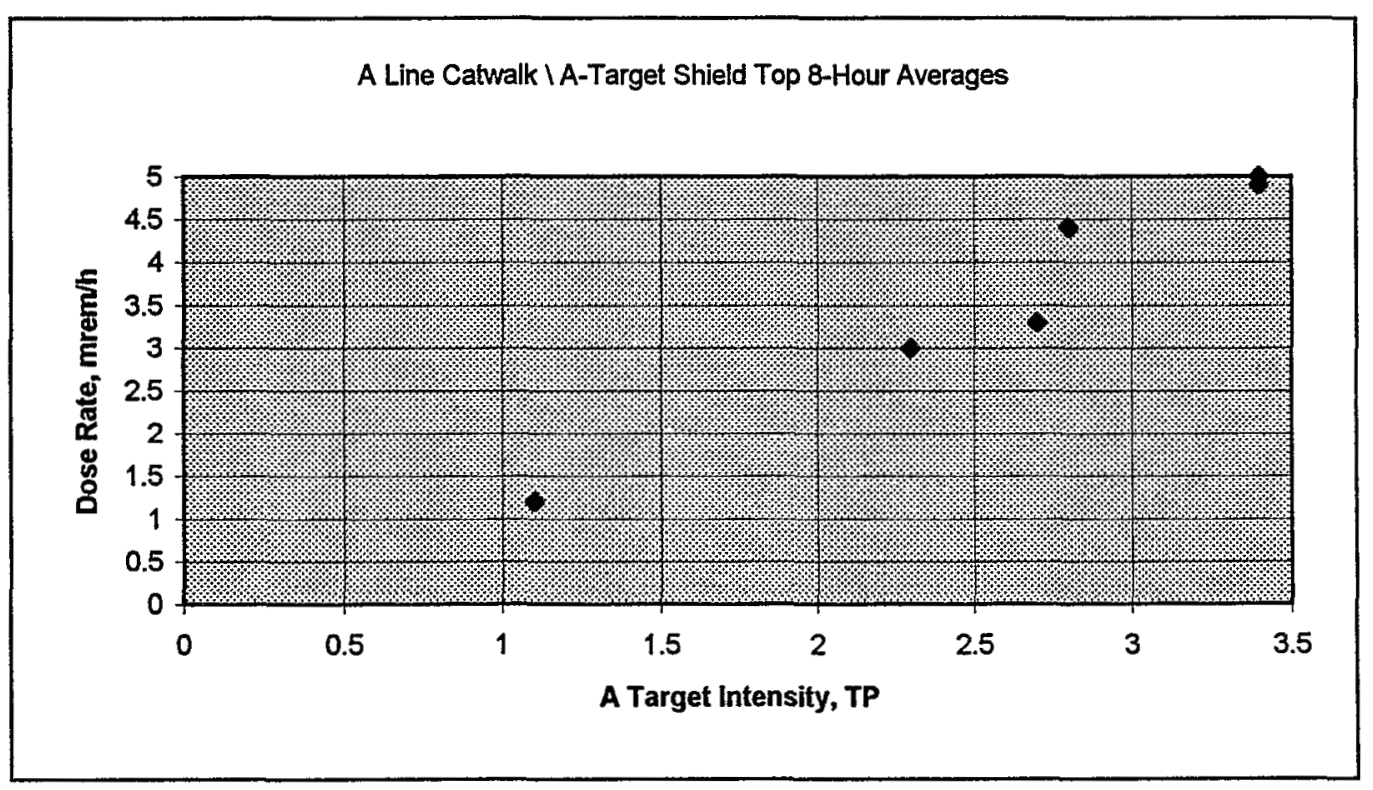

\section{Survey Instrument Measurements}

During the 16-hour study period, spot surveys were performed at or near the A and A1 Lines with an HP1010 survey meter that has a radiation weighting factor set at 5 . The maximum radiation level was observed in the A Line and was $60 \mathrm{mrem} / \mathrm{h}$ at $4.5 \mathrm{TP}$.

The A1 area survey with an HP1010 indicated levels as high as $12 \mathrm{mrem} / \mathrm{h}$ near the A1 beam pipe that is adjacent to the B2 Test Beam area. This particular portion of the A1 Line has a direct view of the water manifold near the B Upstream Target Gate. The intensity in A1 was $1.6 \times 10^{6}$ particles per pulse. Levels at the entrance to the MPS Control Room, which is at the end of the A1 Line, were $0.6 \mathrm{mrem} / \mathrm{h}$.

\section{A2 Line, E865}

\section{Radiation Weighting Factor Measurements}

Downstream of $\mathrm{A} 2$ beam dump, the radiation weighting factor equaled 1. The particles leaving the beam dump are believed to be muons. There does not appear to be recent radiation weighting factor measurements near the A2 Line areas. A study in 1992 by J. 
Preisig, when the area was configured differently, showed the radiation weighting factor for neutrons to be 5 .

\section{Average Area Dose Rate and Intensity}

The eight-hour average was recorded by area radiation monitors. The radiation weighting factor used in these instruments is set at 2.5 since the radiation is assumed to be a mixture of photons and neutrons. The results for this area were:

\begin{tabular}{l|l|l|l|} 
Date/Time & $\begin{array}{l}\text { A Target Intensity, } \\
8 \text { hour average, } \\
\text { TP }\end{array}$ & $\begin{array}{l}\text { Top of A2 Beam Stop, } \\
(52) \\
8 \text { hour average, } \\
\text { mrem/h }\end{array}$ & $\begin{array}{l}\text { A2 Beam Line Dose } \\
\text { Rate, (53) } \\
8 \text { hour average, } \\
\text { mrem/h }\end{array}$ \\
\hline Feb 9, 0 to 8 & 2.8 & 1.2 & 1.2 \\
\hline Feb 9, 8 to 4 & 2.7 & 0.7 & 0.8 \\
\hline Feb 9, 4 to 12 & 3.4 & 1.4 & 1.3 \\
\hline Feb 10,0 to 8 & 3.4 & 0.7 & 1.0 \\
\hline Feb 10,8 to 4 & 2.3 & 0.6 & 0.6 \\
\hline Feb 10,4 to 12 & 1.1 & 0.3 & 1.3
\end{tabular}

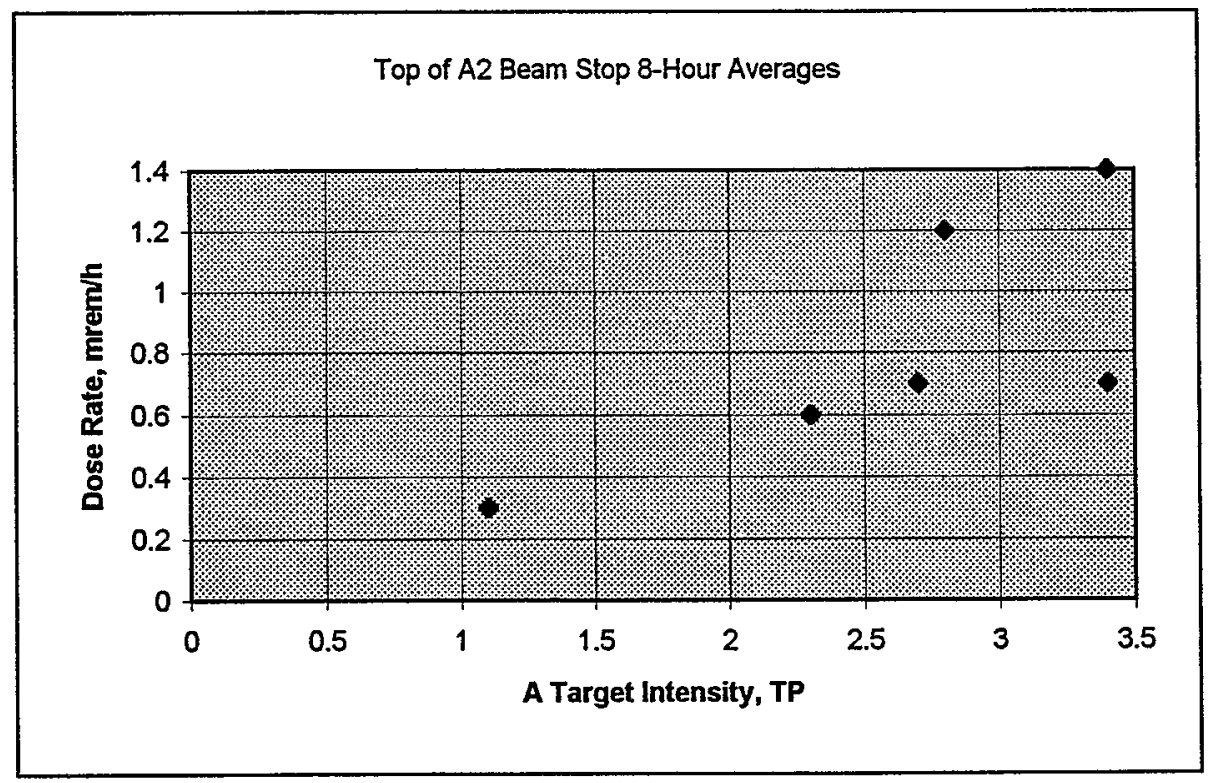




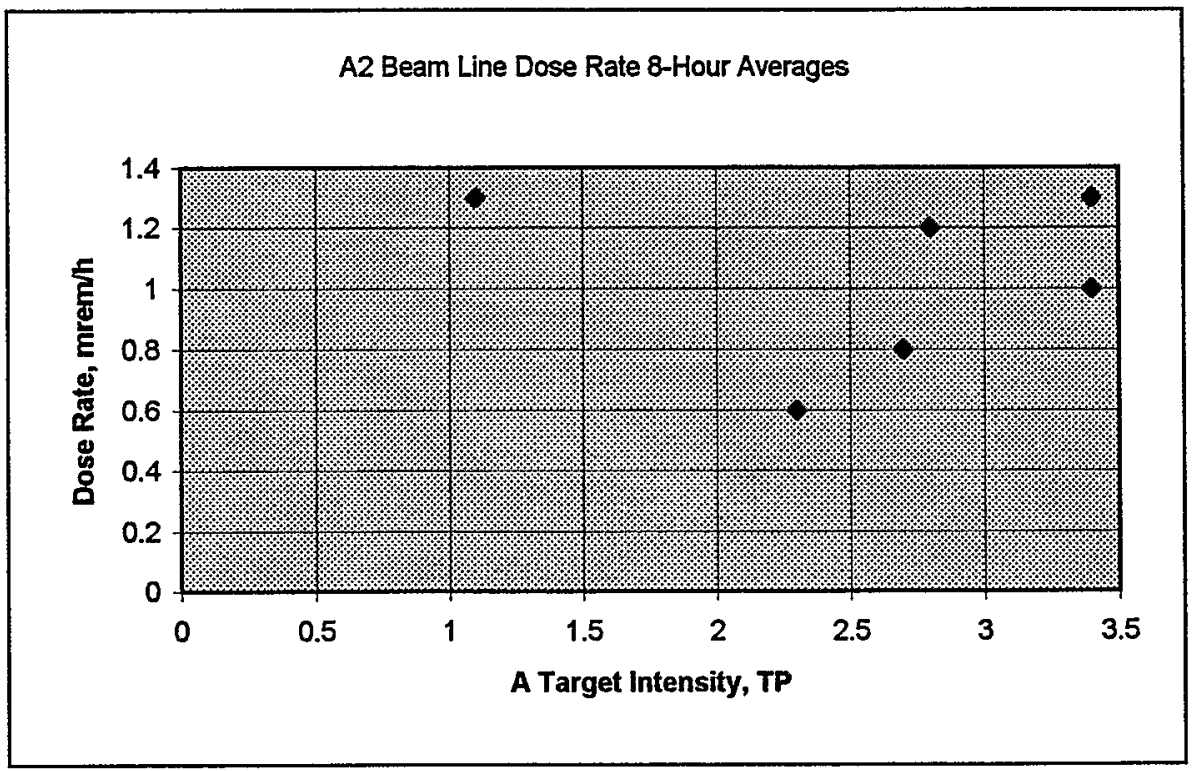

Film Badge Measurements

\begin{tabular}{l|l|l} 
Badge Number & Location For 16 Hours, Feb. 9 and 10, 1995 & Beta Gamma / Neutron Dose, mrem \\
\hline 68481 & E865 Counting House, Ceiling Over Desk & $<10 /<20$
\end{tabular}

On the basis of the film-badge measurement, gamma dose rates were less than $0.6 \mathrm{mrem} / \mathrm{h}$ and neutron dose rates were less than $1.3 \mathrm{mrem} / \mathrm{h}$.

\section{Survey Instrument Measurements}

On Feb. 16, a fault study was performed in the E865 area at $10 \mathrm{TP}$. The occupied areas were $1.1 \mathrm{mrem} / \mathrm{h}$ with the A2 collimator closed, and $2.2 \mathrm{mrem} / \mathrm{h}$ with the collimator open. The survey was performed with an HP1010 which has a radiation weighting factor set at 5. The maximum level seen was $90 \mathrm{mrem} / \mathrm{h}$ at the beam dump and $32 \mathrm{mrem} / \mathrm{h}$ at upstream end of beam dump. At the bridge, a chipmunk recorded $25 \mathrm{mrem} / \mathrm{h}$ with the $\mathrm{A} 2$ collimator open.

\section{B5 Condo, E871}

\section{Radiation Weighting Factor Measurements}

A radiation weighting factor measurement was made at the $\mathrm{B} 5$ Condo with 18 TP reported to be on target on Feb. 10, 1995. The $Q$ was measured to be 3.3. No previous records for radiation weighting factor for this area were located. 


\section{Instantaneous Measurements}
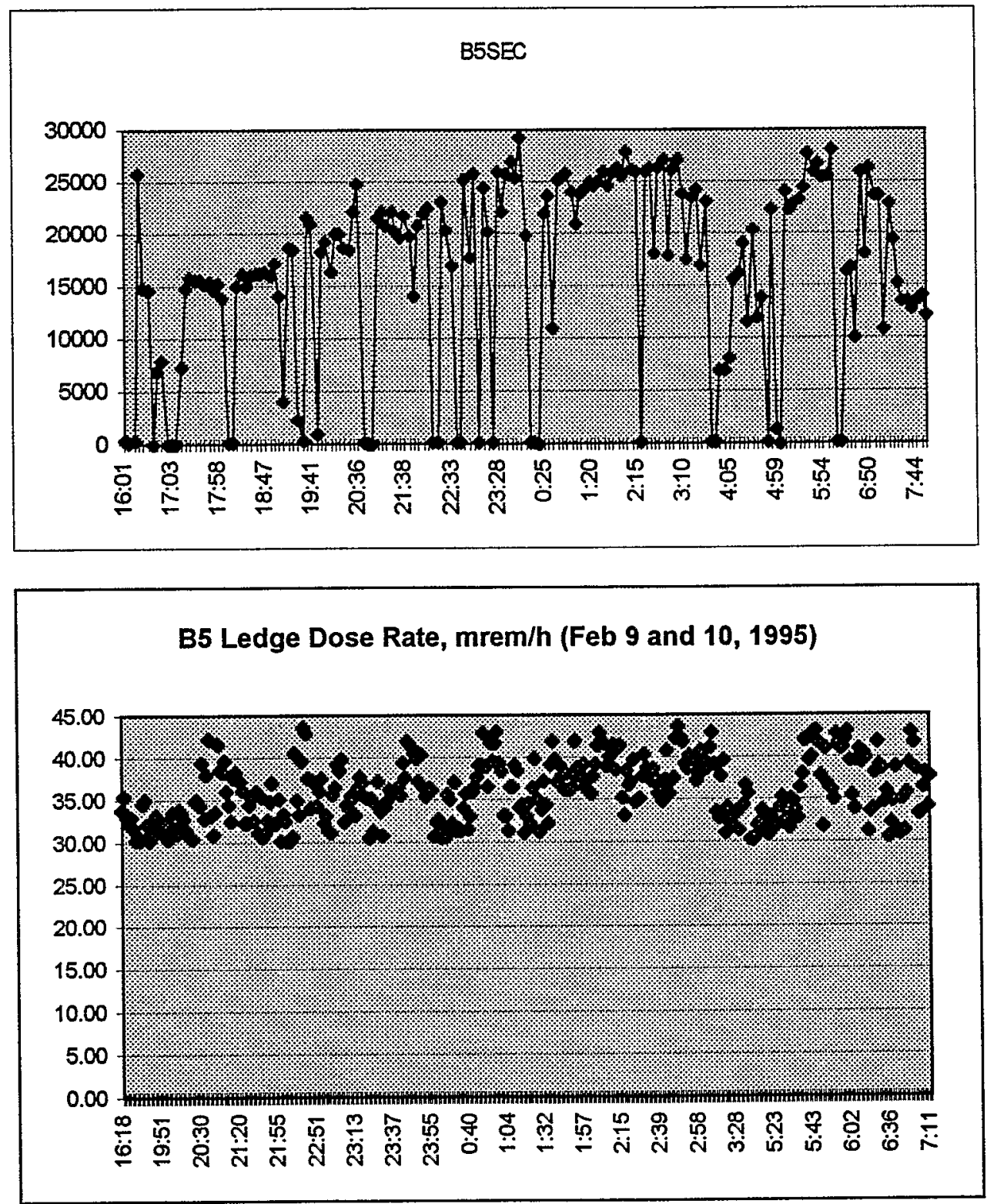

Average Area Dose Rate and Intensity

The eight-hour average was recorded by area radiation monitors. The radiation weighting factor used in these instruments is 2.5 since the radiation is assumed to be a mixture of photons and neutrons. The results for this area were: 


\begin{tabular}{l|l|l|l} 
Date/Time & $\begin{array}{l}\text { B5 Target Intensity, } \\
\text { Thour average, }\end{array}$ & $\begin{array}{l}\text { B5 Condo Dose Rate, } \\
\text { TP }\end{array}$ & $\begin{array}{l}\text { B5 Ledge Dose Rate, } \\
\text { (34) } \\
\text { mrem } / \mathrm{h}\end{array}$ \\
\hline Feb 9, 0 to 8 & 7.4 & 0.9 & $\begin{array}{l}\text { 8 hour average, } \\
\text { mrem/h }\end{array}$ \\
\hline Feb 9,8 to 4 & 0.6 & 0.4 & 23.4 \\
\hline Feb 9, 4 to 12 & 9.0 & 0.9 & 2.8 \\
\hline Feb 10,0 to 8 & 10 & 1.0 & 22 \\
\hline Feb 10,8 to 4 & 5.7 & 0.6 & 26.6 \\
\hline Feb 10,4 to 12 & 2.1 & 0.1 & 14.2 \\
\hline
\end{tabular}
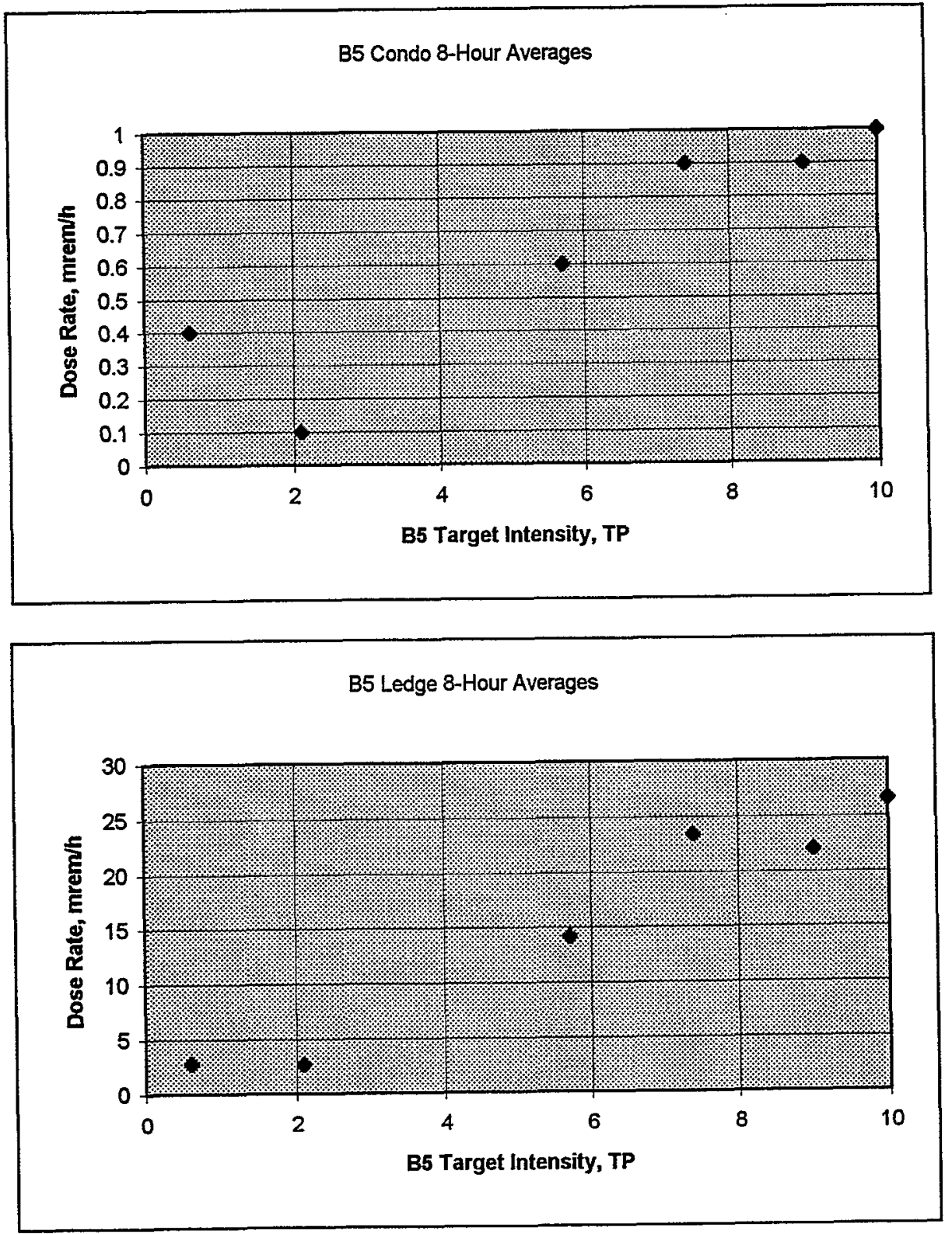
Film-Badge Measurements

\begin{tabular}{l|l|l} 
Badge Number & Location For 16 Hours, Feb. 9 and 10, 1995 & Beta Gamma / Neutron Dose, mrem \\
\hline 68485 & E871 Condo, Second Floor, Control Console & $<10 /<20$ \\
\hline 68486 & E871 Condo, Second Floor, South Wall & $<10 /<20$ \\
\hline 68487 & $\begin{array}{l}\text { E871 Condo, First Floor, Level 2 Room, } \\
\text { Equipment Rack }\end{array}$ & $<10 /<20$
\end{tabular}

On the basis of the film-badge measurement, gamma dose rates were less than $0.6 \mathrm{mrem} / \mathrm{h}$ and neutron dose rates were less than $1.3 \mathrm{mrem} / \mathrm{h}$ in the occupied areas.

Survey Instrument Measurements

During the 16 hour study period, spot surveys were performed at or near the B5 Condo with an HP1010 survey meter. Levels were observed to be 2 to $3 \mathrm{mrem} / \mathrm{h}$ in occupied areas. Outside the Condo, the maximum radiation level was observed in the B upstream area and was $10 \mathrm{mrem} / \mathrm{h}$ at $16 \mathrm{TP}$.

The B5 Condo was also surveyed on February 16 and the dose rates in the occupied areas ranged from 1.2 to $4.5 \mathrm{mrem} / \mathrm{h}$. The general area was about $2.5 \mathrm{mrem} / \mathrm{h}$. The intensity was reported to be $20 \mathrm{TP}$ at this time.

During the study period, spot surveys were performed at or near the B5 beam stop with an HP1010 survey meter. Levels were observed to be $0.5 \mathrm{mrem}$ per hour.

Levels of 1.5 to $5 \mathrm{mrem} / \mathrm{h}$ were measured in the secondary beam enclosure used for the B1 Beam Line which is contiguous to the B5 enclosure. The experiment in B1, E866, is not running at this time but is expected to run during the next heavy ion period.

\section{B2 Test Beam}

\section{Radiation Weighting Factor Measurements}

Radiation weighting factor measurements were made in the upstream Test Beam area near the water manifold near Chipmunk 35. The HP Technicians measured the radiation weighting factor to be 1.5 near the water manifold.

Away from the water manifold and at a distance downstream of about 25 feet, the radiation weighting factor was 5.2 for the neutrons as measured using a Bonner Multisphere Spectrometer on February 22. The neutron dose rate was $1.1 \mathrm{mrem} / \mathrm{h}$. The gamma dose rate at this location was about $2 \mathrm{mrem} / \mathrm{h}$.

Measurements made in 1992 by J. Preisig show the radiation weighting factor to be 6.7 near the B Target Upstream Gate, which is near the water manifold. 


\section{Instantaneous Measurements}

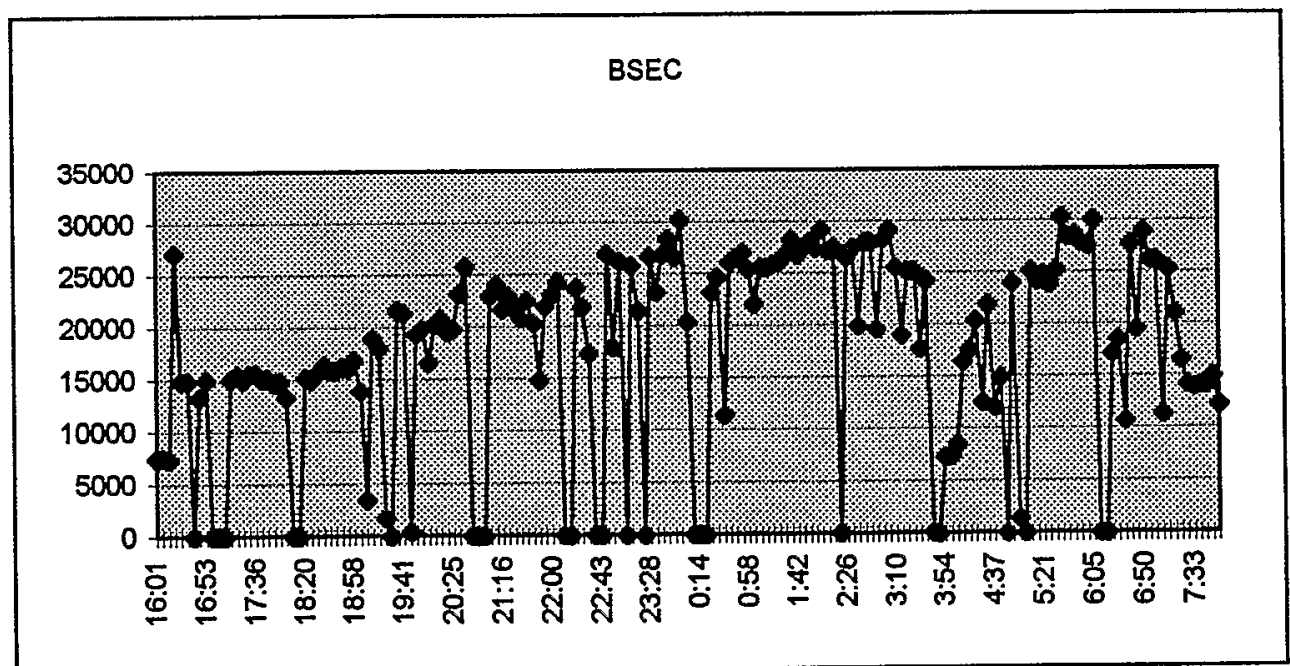

\section{Average Area Dose Rate and Intensity}

The eight-hour average was recorded by area radiation monitors. The radiation weighting factor used in these instruments is 2.5 since the radiation is assumed to be a mixture of photons and neutrons. The results for this area were:

\begin{tabular}{l|l|l|l} 
Date/Time & $\begin{array}{l}\text { B5 Target Intensity, } \\
8 \text { hour average, } \\
\text { TP }\end{array}$ & $\begin{array}{l}\text { B2 Enclosure Fence, } \\
(15) \\
8 \text { hour average, } \\
\text { mrem/h }\end{array}$ & $\begin{array}{l}\text { B Target Downstream } \\
\text { Trench, (35) (Near } \\
\text { Water Manifold) } \\
8 \text { hour average, } \\
\text { mrem/h }\end{array}$ \\
\hline Feb 9, 0 to 8 & 7.4 & 1.3 & 10.3 \\
\hline Feb 9,8 to 4 & 0.6 & 0.7 & 1.8 \\
\hline Feb 9, 4 to 12 & 9.0 & 1.0 & 10.8 \\
\hline Feb 10,0 to 8 & 10 & 1.1 & 11.3 \\
\hline Feb 10,8 to 4 & 5.7 & 0.8 & 6.6 \\
\hline Feb 10,4 to 12 & 2.1 & 0.4 & 1.3
\end{tabular}



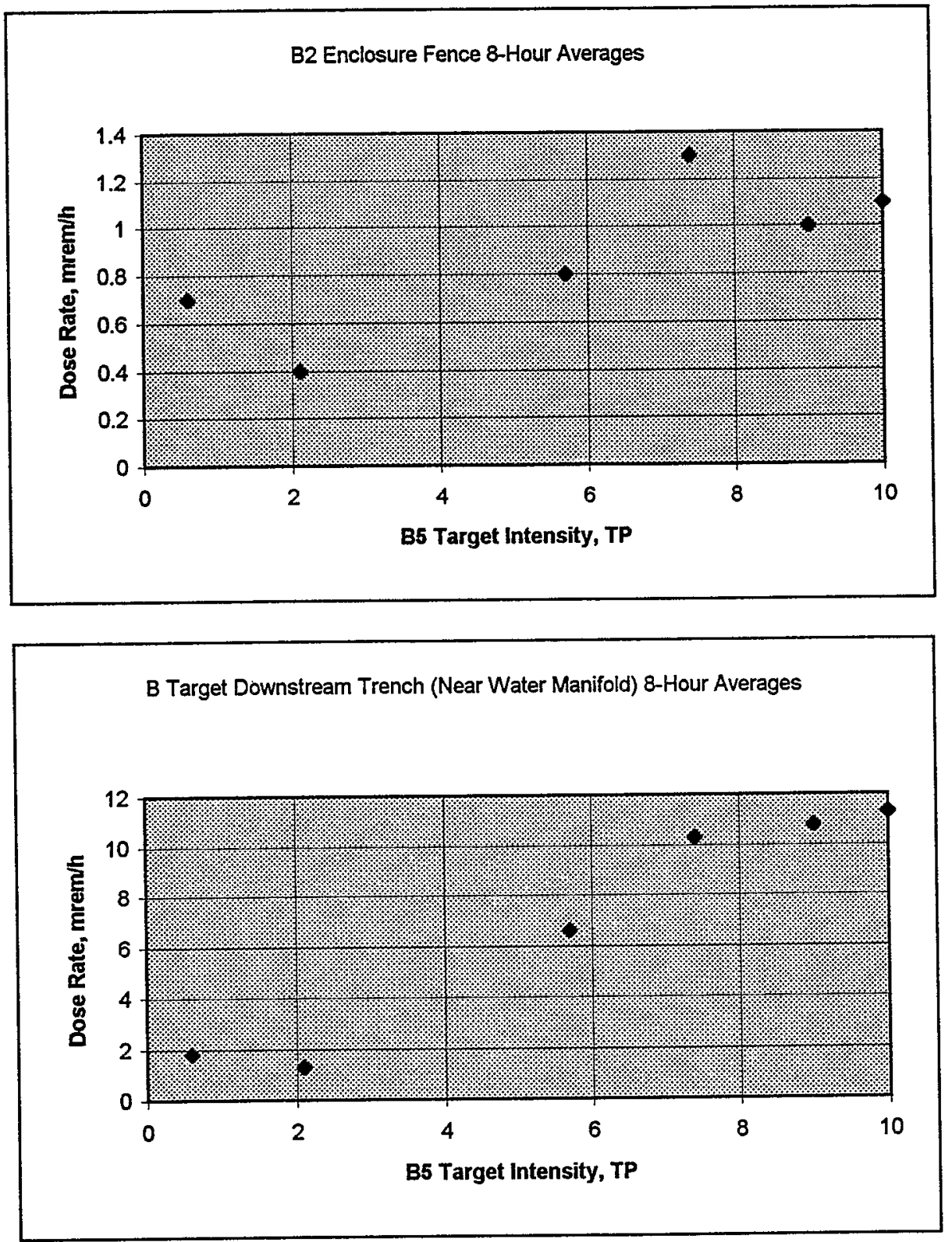

Film Badge Measurements

\begin{tabular}{l|l|l} 
Badge Number & Location For 16 Hours, Feb. 9 and 10, 1995 & Beta Gamma / Neutron Dose, mrem \\
\hline 68482 & $\begin{array}{l}\text { Chipmunk 35 near water manifold near B2 } \\
\text { Test Beam. }\end{array}$ & $60 /<20$ \\
\hline 68483 & $\begin{array}{l}\text { B2 Test Beam about 1/2 way down the fenced } \\
\text { area. }\end{array}$ & $<10 /<20$ \\
\hline 68484 & B2 Test Beam Experimental Gate. & $<10 /<20$
\end{tabular}

On the basis of the film-badge measurements, the average neutron dose rate was less than $1.3 \mathrm{mrem} / \mathrm{h}$ in the B2 Test Beam area. 
The average gamma dose rate recorded by the film badge near the water manifold was about $4 \mathrm{mrem} / \mathrm{h}$. Since the chipmunk response to gamma radiation is forced to be 2.5 times greater than the film badge, the chipmunk near the water manifold is in agreement with this film-badge result.

The average gamma dose rate along the B2 Test Beam fenced area was less than 0.6 $\mathrm{mrem} / \mathrm{h}$ during the study period.

\section{Survey Instrument Measurements}

A survey of the Test Beam Area was made using a HP1010 which has a radiation weighting factor set at 5 . The levels ranged from 2 to $3 \mathrm{mrem} / \mathrm{h}$ along the Test Beam fenced area in the area normally occupied by Users where mixed radiation is likely. The maximum dose rate observed along this fence was $10 \mathrm{mrem} / \mathrm{h}$ with $16 \mathrm{TP}$ in B Line. The dose rate at a desk located near a water manifold at the upstream end of the Test Beam was measured to be $11 \mathrm{mrem} / \mathrm{h}$ using the HP1010. If the HP1010 response was primarily from photons from the nearby activated water, then the dose rate at this particular desk was actually 2 to $3 \mathrm{mrem} / \mathrm{h}$. This is in reasonable agreement with the average gamma dose rate derived from film-badge measurements at this location. The majority of other desks in the Test Beam are located in a mixed radiation field, however.

\section{Contamination}

At about midnight February 9, air samples near the B Target Gate near Chipmunk 35 showed gross beta concentrations of $1.2 \times 10^{-9}$ and $4.1 \times 10^{-10} \mu \mathrm{Ci}$. This corresponds to $1.5 \times 10^{-5}$ and $5 \times 10^{-6} \mathrm{mrem} / \mathrm{h}$ assuming the nuclide is $\mathrm{C}-11$ which was likely. One of the work desks in the B2 Test Beam near the B Gate showed 1,100 dpm.

\section{$\underline{\mathrm{C} 1, \mathrm{E} 850}$}

Radiation Weighting Factor Measurements

No radiation weighting factor measurements were made during this study. Previous studies of radiation weighting factor for this area were not located. 
Instantaneous Measurements
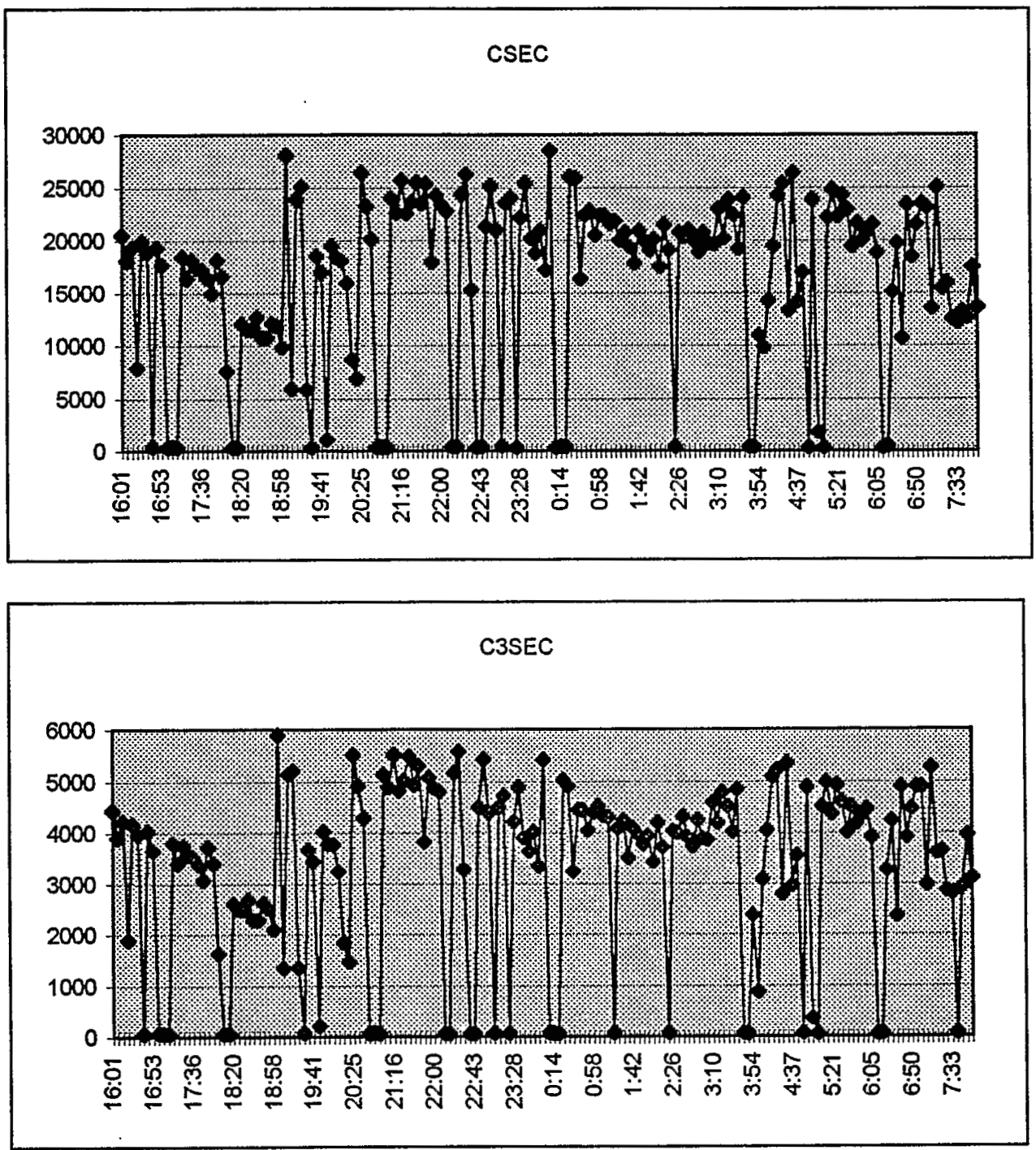

Average Area Dose Rate and Intensity

The eight-hour average was recorded by area radiation monitors. The radiation weighting factor used in these instruments is 2.5 since the radiation is assumed to be a mixture of photons and neutrons. The results for this area were: 


\begin{tabular}{l|l|l|l|l} 
Date/Time & $\begin{array}{l}\text { C Target Intensity, } \\
\text { 8 hour average, } \\
\text { TP }\end{array}$ & $\begin{array}{l}\text { C3 Target Intensity, } \\
\text { 8 Hour Average, } \\
\text { TP }\end{array}$ & $\begin{array}{l}\text { C1 Line Platform } \\
\text { Downstream of } \\
\text { C1P4, (70) } \\
8 \text { hour average, } \\
\text { mrem/h }\end{array}$ & $\begin{array}{l}\text { C1 Experimental } \\
\text { Area Platform } \\
\text { (EVA), (71) } \\
\text { 8 hour average, } \\
\text { mrem/h }\end{array}$ \\
\hline Feb 9, 0 to 8 & 7.9 & 1.9 & 3.6 & 0.4 \\
\hline Feb 9,8 to 4 & 6.0 & 1.8 & 1.7 & 0.2 \\
\hline Feb 9, 4 to 12 & 8.4 & 2.2 & 3.6 & 0.4 \\
\hline Feb 10,0 to 8 & 9.3 & 2.2 & 3.9 & 0.5 \\
\hline Feb 10,8 to 4 & 6.0 & 1.7 & 2.4 & 0.3 \\
\hline Feb 10,4 to 12 & 1.7 & 0.4 & 0.9 & 0.1
\end{tabular}
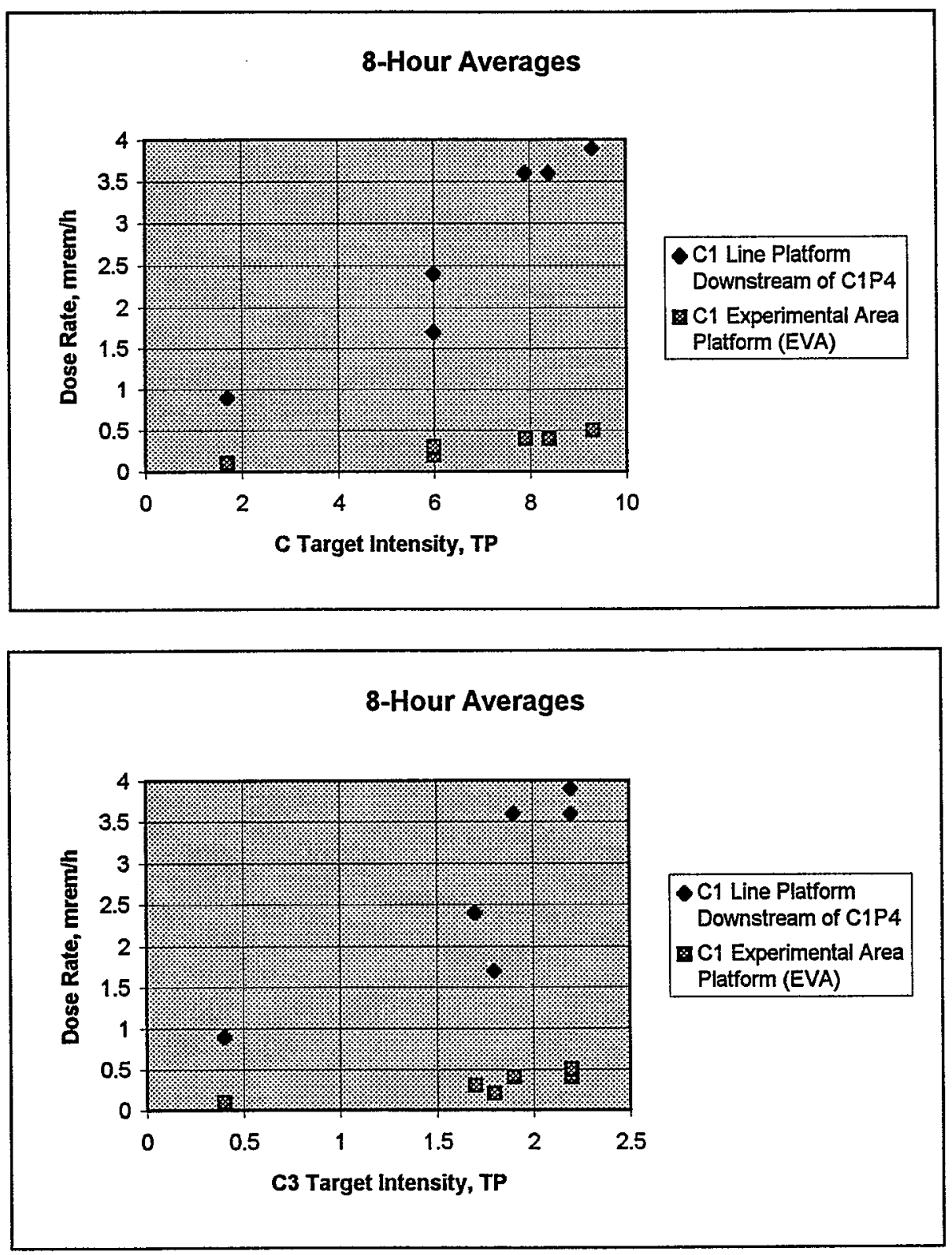


\section{Film Badge Measurements}

\begin{tabular}{l|l|l} 
Badge Number & Location For 16 Hours, Feb. 9 and 10, 1995 & Beta Gamma / Neutron Dose, mrem
\end{tabular} \begin{tabular}{l|l}
68488 & E850 Trailer.
\end{tabular} $<10 /<20$

On the basis of the film-badge measurements, the neutron dose rate was less than 1.3 $\mathrm{mrem} / \mathrm{h}$. The gamma dose rate was less than $0.6 \mathrm{mrem} / \mathrm{h}$ during the study period.

\section{Survey Instrument Measurements}

During the study period, spot surveys were performed at or near the $\mathrm{Cl}$ beam stop with an HP1010 survey meter. The radiation weighting factor for this instrument is set at 5 . Levels were observed to be 0.4 mrem per hour.

\section{$\underline{\mathrm{C} 8, \mathrm{E} 890}$}

\section{Radiation Weighting Factor Measurements}

None were made during this study period. During 1994, J. Preisig measured a radiation weighting factor of 5.8 for neutrons in this area.

\section{Average Area Dose Rate and Intensity}

The eight-hour average was recorded by nearby area-radiation monitors. The radiation weighting factor used in these instruments is 2.5 since the radiation is assumed to be a mixture of photons and neutrons. The results for this area were:

\begin{tabular}{l|l|l|l} 
Date/Time & $\begin{array}{l}\text { C Target Intensity, } \\
8 \text { hour average, } \\
\text { TP }\end{array}$ & $\begin{array}{l}\text { C3 Target Intensity, } \\
\text { 8 Hour Average, } \\
\text { TP }\end{array}$ & $\begin{array}{l}\text { Upstream of C8 Gate, (74) } \\
\text { mour average, } \\
\text { mrem/h }\end{array}$ \\
\hline Feb 9,0 to 8 & 7.9 & 1.9 & 1.4 \\
\hline Feb 9, 8 to 4 & 6.0 & 1.8 & 0.9 \\
\hline Feb 9, 4 to 12 & 8.4 & 2.2 & 1.4 \\
\hline Feb 10,0 to 8 & 9.3 & 2.2 & 1.5 \\
\hline Feb 10,8 to 4 & 6.0 & 1.7 & 1.0 \\
\hline Feb 10,4 to 12 & 1.7 & 0.4 & 0.3
\end{tabular}



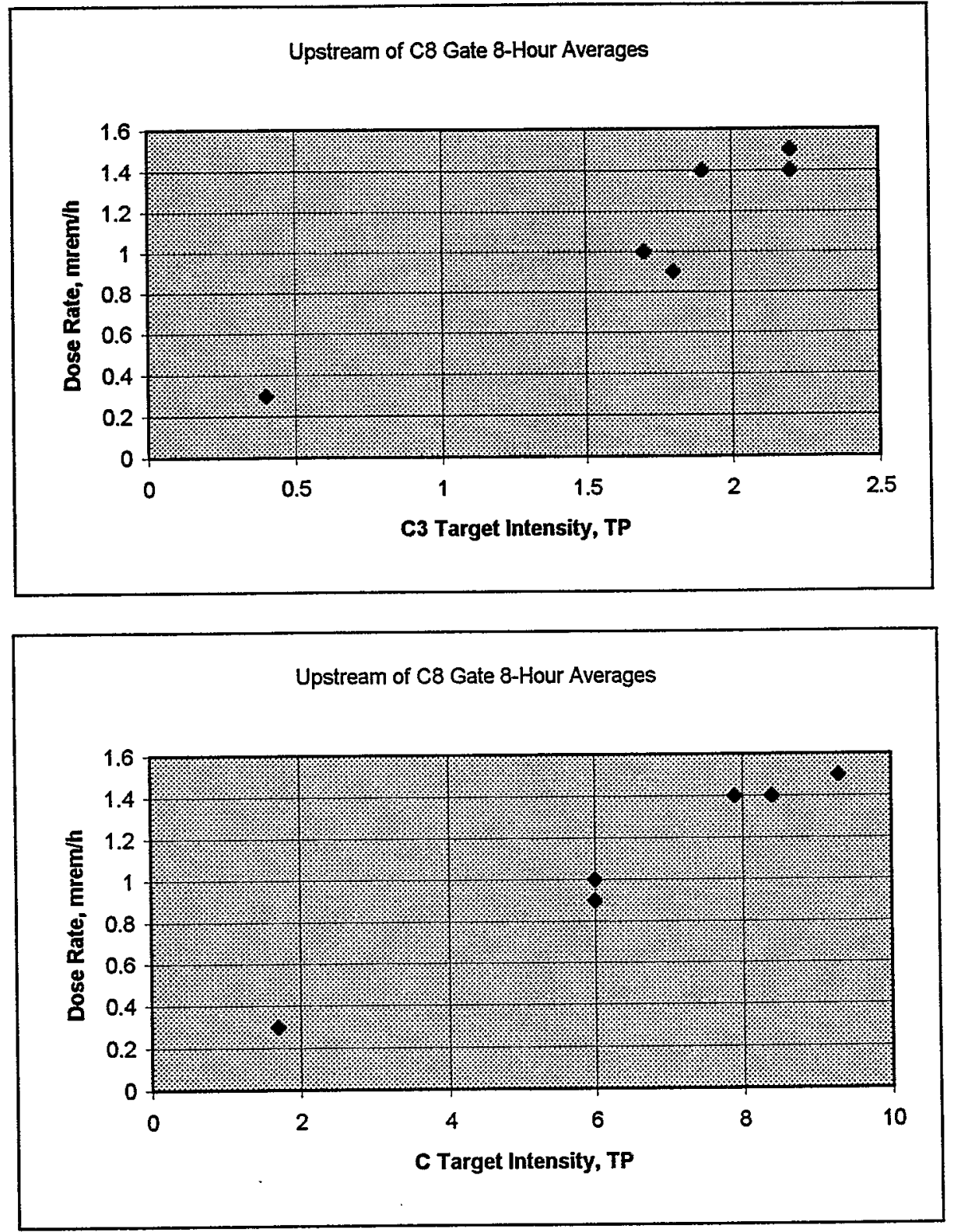

\section{Film Badge Measurements}

\begin{tabular}{l|l|l} 
Badge Number & Location For 16 Hours, Feb. 9 and 10, 1995 & Beta Gamma / Neutron Dose, mrem \\
\hline 68493 & E890 Trailer. & $<10 /<20$ \\
\hline 68494 & Bottle Rack near Cooling Tower 2 & $80 /<20$ \\
\hline 68489 & C3 Target Gate & $50 /<20$
\end{tabular}

On the basis of the film-badge measurements, the neutron dose rate was less than 1.3 $\mathrm{mrem} / \mathrm{h}$. The average gamma dose rate at the bottle storage rack near Cooling Tower 2 was $5 \mathrm{mrem} / \mathrm{h}$ during the study period. This Tower is across the street from Building 912 , and about 60 feet from the E890 trailer. The gamma dose rate in the E890 trailer was less than $0.6 \mathrm{mrem} / \mathrm{h}$ on the basis of film badge measurements. 
The C3 Target Gate is located in an area where a spot check using the HP1010 indicated $18 \mathrm{mrem} / \mathrm{h}$. This film badge had a view of the nearby water-cooled bus that indicated 56 $\mathrm{mrem} / \mathrm{h}$ on the HP1010. Thus, the film badge average of $3.1 \mathrm{mrem} / \mathrm{h}$ gamma compares with the HP1010 measurement.

\section{Survey Instrument Measurements}

During the study period, spot surveys were performed at or near the E890 trailer with an HP1010 survey meter. The radiation weighting factor for this instrument is set at 5 . Levels in the E890 trailer were observed to be 3.4 to $4.2 \mathrm{mrem}$ per hour sometime between midnight February 9 and 5:15 AM on February 10. Assuming the HP1010 is responding to the photon radiation from Cooling Tower 2 , then this would translate into 0.7 to $0.8 \mathrm{mrem} / \mathrm{h}$ in the E890 trailer. This level was measured during the highest intensity period of the study.

The HP1010 measurements which were weighted for neutrons rose to $5.6 \mathrm{mrem} / \mathrm{h}$ in the roadway between Cooling Tower 2 and E890, and were 20 to $30 \mathrm{mrem} / \mathrm{h}$ near the bottle rack. For gamma radiation, this translates to $1 \mathrm{mrem} / \mathrm{h}$ in the roadway and 4 to $6 \mathrm{mrem} / \mathrm{h}$ at the bottle rack near the cooling tower.

The maximum dose rate along the $C$ Line was about $77 \mathrm{mrem} / \mathrm{h}$ using the HP1010 near the water-cooled bus area. The level is probably closer to $15 \mathrm{mrem} / \mathrm{h}$. Weighted HP1010 rates as high as 12 to $13 \mathrm{mrem} / \mathrm{h}$ were measured on the $\mathrm{C} 8$ platform. Weighted HP 1010 rates along the primary beam shield walls from E787 to E890 ranged between 10 and 20 $\mathrm{mrem} / \mathrm{h}$.

\section{$\underline{\mathrm{C} 4, \mathrm{E} 787}$}

Radiation Weighting Factor Measurements

None were made during this study period. During 1994, J. Preisig measured a radiation weighting factor of 5.8 for neutrons in this area. 


\section{Instantaneous Measurements}

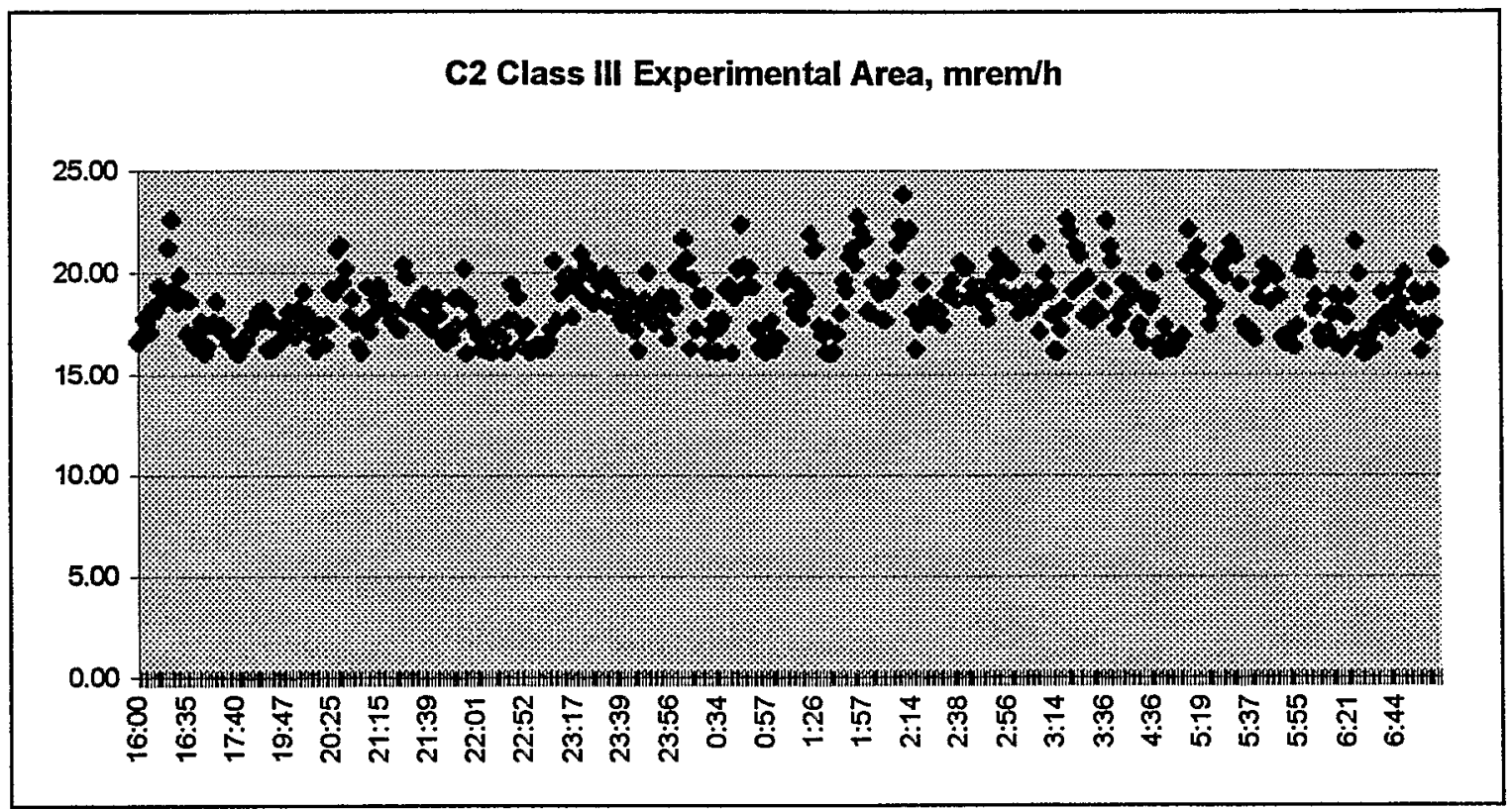

\section{Average Area Dose Rate and Intensity}

The eight-hour average was recorded by nearby area-radiation monitors. The radiation weighting factor used in these instruments is 2.5 since the radiation is assumed to be a mixture of photons and neutrons. The results for this area were:

\begin{tabular}{l|l|l|l} 
Date/Time & $\begin{array}{l}\text { C Target Intensity, } \\
8 \text { hour average, } \\
\text { TP }\end{array}$ & $\begin{array}{l}\text { C3 Target Intensity, } \\
8 \text { Hour Average, } \\
\text { TP }\end{array}$ & $\begin{array}{l}\text { C4 Experimental Trailer, } \\
(37) \\
8 \text { hour average, } \\
\text { mrem/h }\end{array}$ \\
\hline Feb 9, 0 to 8 & 7.9 & 1.9 & 0.7 \\
\hline Feb 9, 8 to 4 & 6.0 & 1.8 & 0.5 \\
\hline Feb 9, 4 to 12 & 8.4 & 2.2 & 0.8 \\
\hline Feb 10, 0 to 8 & 9.3 & 2.2 & 0.9 \\
\hline Feb 10,8 to 4 & 6.0 & 1.7 & 0.5 \\
\hline Feb 10, 4 to 12 & 1.7 & 0.4 & 0.1
\end{tabular}



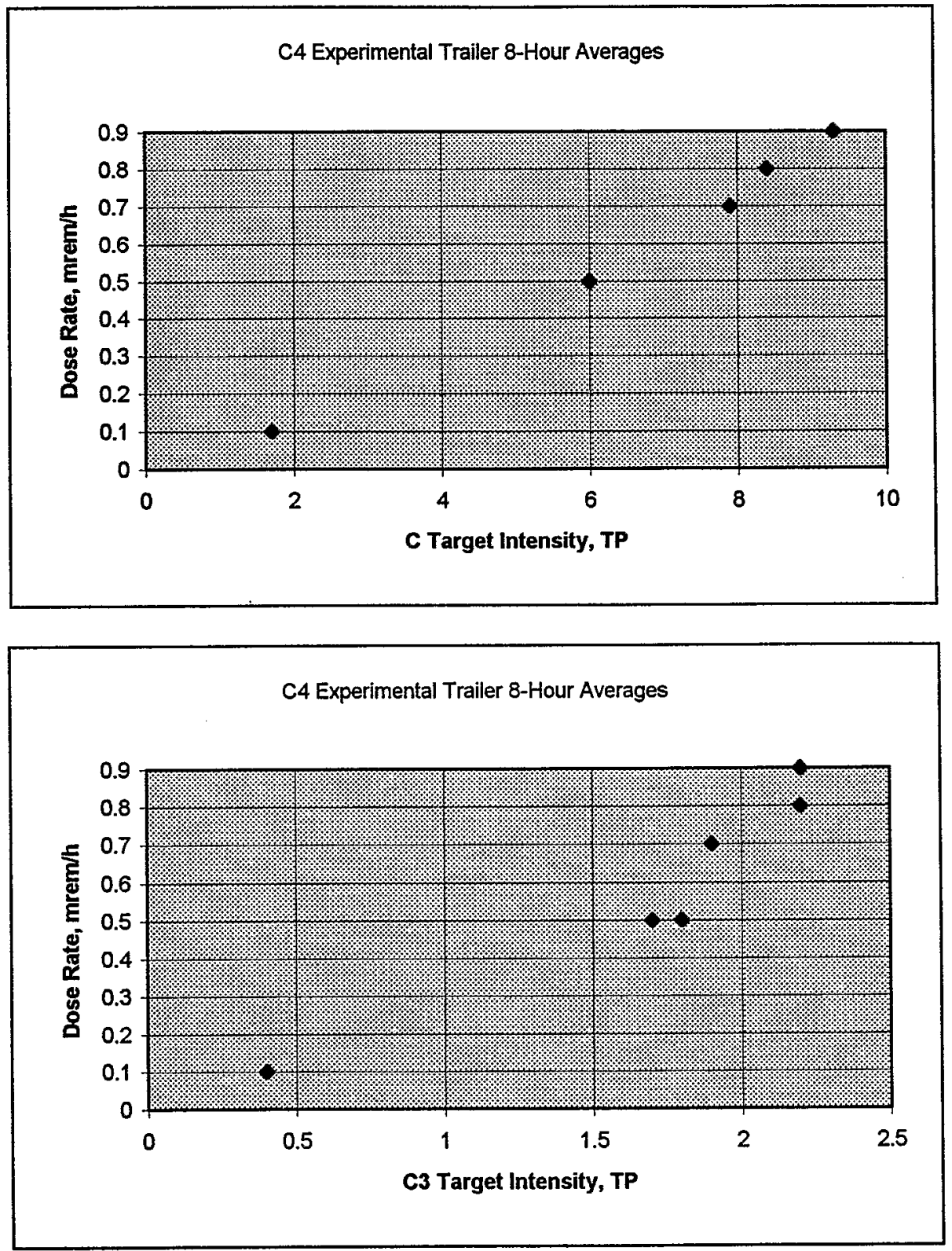

\section{Film Badge Measurements}

\begin{tabular}{l|l|l} 
Badge Number & Location For 16 Hours, Feb. 9 and 10, 1995 & Beta Gamma / Neutron Dose, mrem \\
\hline 68490 & E787 Counting House, First Floor, Center. & $<10 /<20$ \\
\hline 68491 & $\begin{array}{l}\text { E787 Counting House, First Floor, North } \\
\text { Wall. }\end{array}$ & $<10 /<20$ \\
\hline 68492 & E787 Counting House, Second Floor, Center. & $<10 /<20$
\end{tabular}

On the basis of the film-badge measurements, the neutron dose rate was less than 1.3 $\mathrm{mrem} / \mathrm{h}$. The gamma dose rate in the E787 counting house was less than $0.6 \mathrm{mrem} / \mathrm{h}$.

\section{Survey Instrument Measurements}


A measurement with an HP1010 was made between midnight February 9 and 5 AM February 10 near the LESB III north gate. This is near the chipmunk located at the Class III experimental area for E787. The measurement indicated about $12 \mathrm{mrem} / \mathrm{h}$ which is a few $\mathrm{mrem} / \mathrm{h}$ less than that indicated by the nearby chipmunk.

The roadway along side the E787 counting house and the roadway near the C Target Gate measured 2 to $3 \mathrm{mrem} / \mathrm{h}$ using the HP1010 survey meter which has a set radiation weighting factor of 5 . Given the proximity of water pipes and of Cooling Tower 2 , the HP1010 readings should be interpreted as 0.4 to $0.6 \mathrm{mrem} / \mathrm{h}$ in this roadway area.

D6, E813

\section{Radiation Weighting Factor Measurements}

None were made during this study period. During 1994, J. Preisig measured a radiation weighting factor of 6.2 for neutrons in this area. It is noted that neutron dose rates were less than $0.2 \mathrm{mrem} / \mathrm{h}$ at the time, and that the total area-radiation-level was dominated by gamma radiation due to shine from water pipes.

Instantaneous Measurements

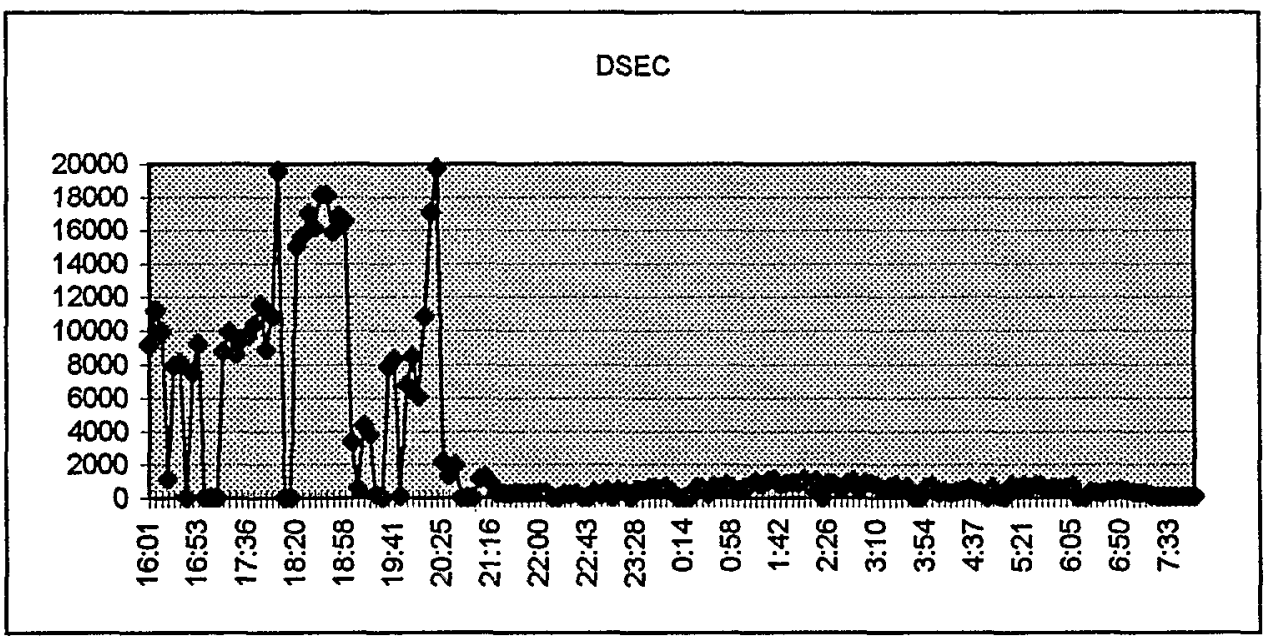


Average Area Dose Rate and Intensity

\begin{tabular}{l|l|l|l|l} 
Date/Time & $\begin{array}{l}\text { D Target Intensity, } \\
\text { 8 hour average, } \\
\text { TP }\end{array}$ & $\begin{array}{l}\text { Top of D6 Beam } \\
\text { Stop, (21) } \\
\text { 8 Hour Average, } \\
\text { TP }\end{array}$ & $\begin{array}{l}\text { North Gate, (22) } \\
\text { 8 hour average, } \\
\text { mrem/h }\end{array}$ & $\begin{array}{l}\text { D-6 Beam Stop, (18) } \\
\text { 8 hour average, } \\
\text { mrem/h }\end{array}$ \\
\hline Feb 9,0 to 8 & 1.4 & 7.7 & 13 & 1.6 \\
\hline Feb 9,8 to 4 & 2.7 & 5.4 & 7.0 & 1.2 \\
\hline Feb 9,4 to 12 & 2.9 & 1.9 & 4.6 & 1.6 \\
\hline Feb 10, 0 to 8 & 0.31 & 8.7 & 5.7 & 1.7 \\
\hline Feb 10, 8 to 4 & 0.94 & 4.9 & 2.5 & 1.2 \\
\hline Feb 10,4 to 12 & 0.14 & 0.1 & 0.4 & 0.5
\end{tabular}

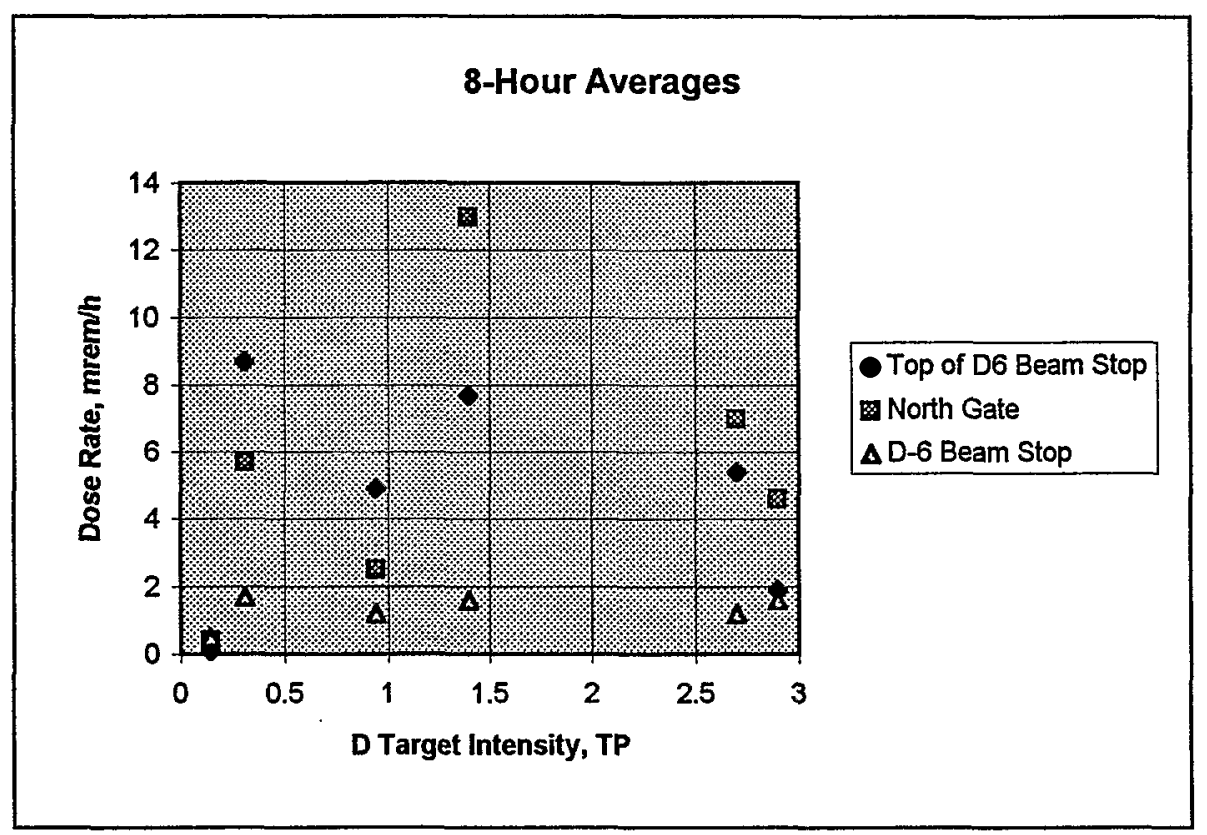

The dose rates in and around the D Line could not be related in any discernible way to intensity changes on the $\mathrm{D}$ target. The $\mathrm{D}$ target was minimally used during most of the study period. Changes in dose rates along the $\mathrm{D}$ Line may have been influenced by water pipes filled with water from other beam lines. They may also have been influenced by radiation levels in the AGS Ring which is proximate to D Line.

Film Badge Measurements

\begin{tabular}{l|l|l} 
Badge Number & Location For 16 Hours, Feb. 9 and 10, 1995 & Beta Gamma / Neutron Dose, mrem \\
\hline 68481 & E813 Counting House. & $<10 /<20$ \\
\hline 68478 & D Corral Gate & $20 /<20$ \\
\hline 68479 & North Gate Near Chipmunk 22 & $40 /<20$
\end{tabular}

On the basis of the film-badge measurements, the neutron dose rate was less than 1.3 $\mathrm{mrem} / \mathrm{h}$. The average gamma dose rate in the counting house was less than $0.6 \mathrm{mrem} / \mathrm{h}$. 
The gamma dose rate at the North Gate to the AGS Ring was less than $2.5 \mathrm{mrem} / \mathrm{h}$ on the basis of the film badge measurement. This film badge location was near a water tank. The nearby Chipmunk 22 shows an average of $5.2 \mathrm{mrem} / \mathrm{h}$ during this same period. This is in reasonable agreement with the film-badge result if one assumes Chipmunk 22

predominantly sees gamma radiation at this location.

$$
\text { Survey Instrument Measurements }
$$

$\sin ^{2}$

A spot measurement with an HP1010 was made between midnight February 9 and 5 AM February 10 along the D Line. The measurement indicated about $4 \mathrm{mrem} / \mathrm{h}$. 
Instantaneous Dose Rate at Hot Spots

\section{Dose Rate at Old D Gate Trench (Crotch Between B and $C$ Lines), $\mathrm{mrem} / \mathrm{h}$}

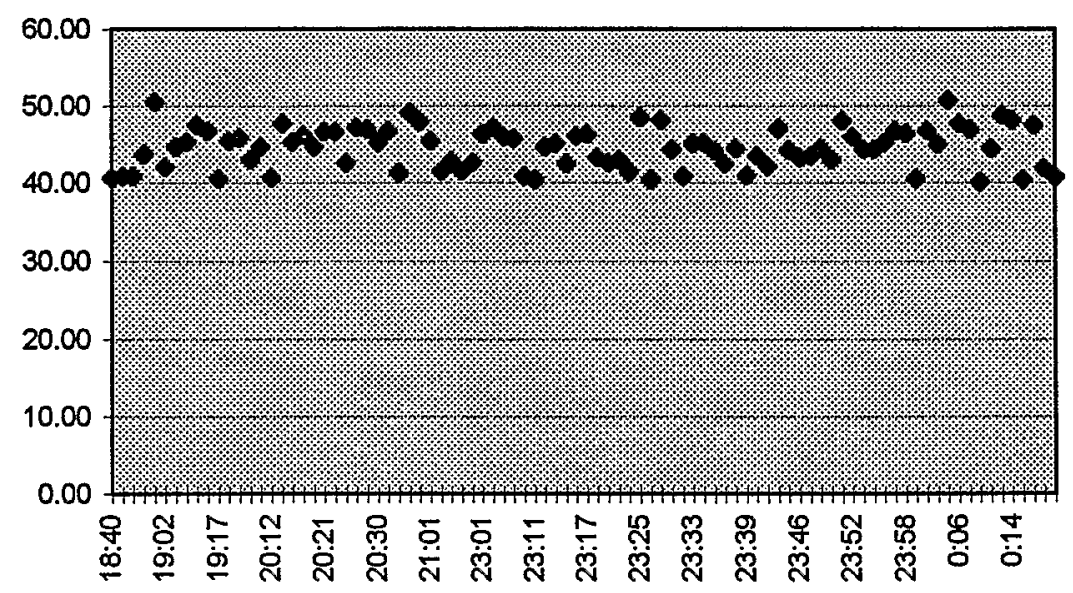

Target Desk, mrem/h

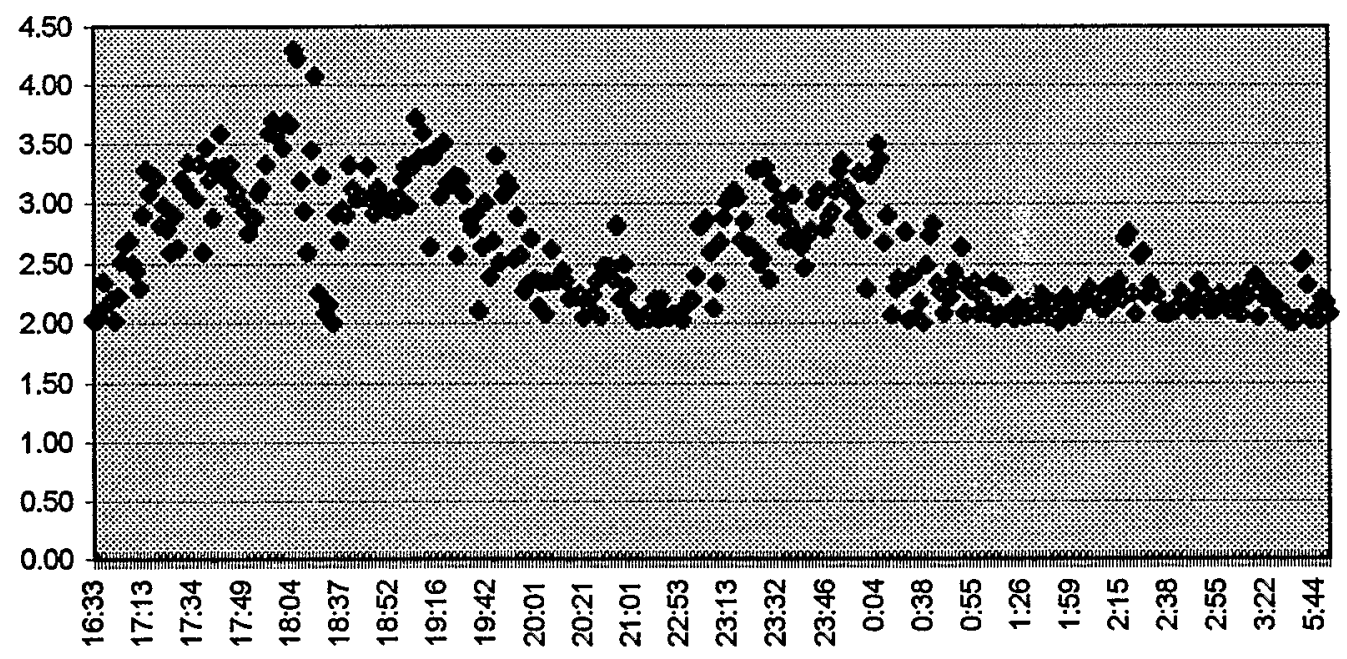



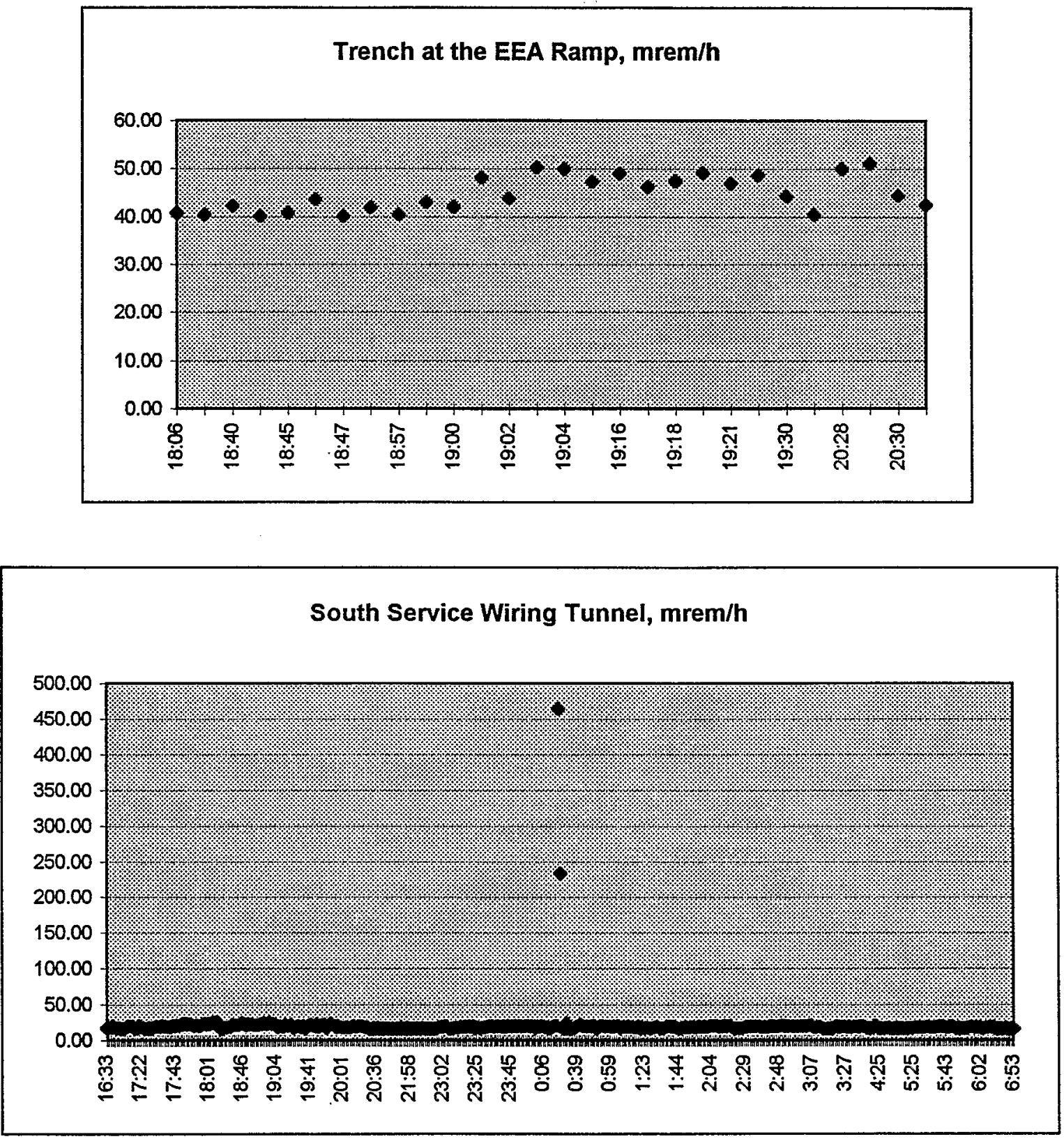